\title{
The New Turkish Republic
}

Graham E. Fuller

Washington, DC: United States Institute of Peace Press, 2008. 196 pages.

This policy book purports to advise American decision makers about the changes and transformations taking place in Turkey's politics and foreign policy, as well as their reasons and implications. It further counsels Washing- 
ton on how to deal with the novelties that they may engender. Graham Fuller argues that Turkey, under Mustafa Kemal Ataturk and his successors, underwent an imposed "cultural lobotomy" designed to induce a national "amnesia" about its Islamic and Ottoman past (p. 17). This condition, however, is ending, for Turkey seems to be experiencing a counter-dynamic and a "return of history," away from what the author deems a "transient geopolitical aberration from a long norm" (p. 8).

Fuller makes his point by asserting, first, that Turkey is again becoming part of the Middle East and examining its historical trajectory and legacies. Second, by highlighting the increasing divergence in Turkish-American relations due to the changing circumstances related to the Soviet collapse and the reordering of European politics, he sees an American regional agenda at odds with Turkish national and geopolitical interests, as well as a Turkish strategic opening to the Muslim world, Eurasia, Russia, and China, as alternative political and economic options. The author's broad conclusion is that how Turkey will act in the Middle East and the Muslim world will largely depend on the "complex interplay" between the United States, the European Union, and Turkey's non-western interests (p. 9). Such a "comeback," in any case, is likely to partially dilute and complicate, as well as enrich and complement, Turkey's links with the "West" (p. 8).

The book is divided into three parts. The first part (six chapters) traces Turkey's historical trajectory as regards the tumultuous political, cultural, and psychological events of the late Ottoman period, the Kemalist reform era, Turkey's embrace of the West during the early days of the cold war, and the present time, in which it is rapidly moving toward greater foreign policy independence and rediscovering its Islamic heritage (pp. 8-10). The second part (ten chapters) analyzes its relations with the Arab and Muslim worlds, as well as with American, Eurasian, European, and Israeli actors, and attempts to observe and underscore existing tendencies that Washington may be able to capitalize upon to protect its interests. Finally, in part three (two chapters) Fuller attempts to project and predict Turkey's future trajectory and advises on possible and/or alternative American policy options.

The impression one gets from going through what the author is in fact trying to say, as well as reading between the lines, is that while there may be significant changes in Turkish foreign policy orientations that may alter the nature of its historical ties with the United States, the latter should "appropriate" such developments and deal with them pragmatically. It should accept them while adjusting and manipulating them within a general policy framework that would contextualize such dynamics within a structure of 
continuity pertaining to American national interests, so that the more things change the more they stay the same.

The questions then become what this entails and what Fuller seems to hint at, imply, or propose outright in his book. Essentially, American interests require Turkey to be a "pivotal state" in the Muslim world along the same lines, for instance, of post-Camp David Egypt in the Arab world - in their respective worlds but not of it, to borrow from Biblical language.* This necessitates Turkey's retreat from its Kemalist nationalist and isolationist policy vis-à-vis the Arab and Muslim worlds in favor of a "moderate" depoliticized Islamist orientation, one totally respectful of the concept of state structure (pp. 53 and vi). This "new look" would presumably be represented not only by the Justice and Development Party (JDP), upon which Fuller imposes the "Islamist" label even though the party does not so designate itself (pp. 51-52), but also potentially by Fethullah Gülen's apolitical and communitarian Sufi movement (pp. 8, 56, and 61).

The latter's active engagement in "worldly" life, according to Fuller, makes it almost "Calvinist" in character (p. 57). Implied here is an attempt to move Islamists everywhere away from state-challenging attitudes and toward profitable business concerns, such as Islamic banking. The purpose is to offer political Islamists financial stakes in secure and predictable "capitalist interests," thus "domesticating" them (pp. 45-46). Turkey's internal political and economic "success" in this respect would then render it a "state" worth "emulating" (p. 6), particularly by a Muslim world in search of a leader (p. 23). While he is skeptical of whether Turkey may be interested in playing such a role, the country may still be brought to exert significant influence on the region as a whole (p. 23).

This leads to the issue of foreign policy expectations. In general, American interests require Turkey to help undermine Washington's enemies and secure the success of its policies. This would entail a possible engagement in a broad Sunni anti-Shi ite agenda. Despite Turkish unwillingness to get involved in anything of the kind, Fuller does hint that "in the event of serious deterioration" in mutual relations with Iran, such a possibility may present

\footnotetext{
*According to this American understanding of the term, "pivotal states strategy, ..., would encourage integration of new security issues into a traditional, state-centered framework and lend greater clarity to the making of foreign policy. This integration may make some longterm consequences of the new security threats more tangible and manageable. And it would confirm the importance of working chiefly through state governments to ensure stability while addressing the new security issues that make these states pivotal." See Robert S. Chase, Emily B. Hill, and Paul Kennedy, "Pivotal States and U.S. Strategy," Foreign Affairs 75, no. 1 (Jan./Feb. 1996): 37.
} 
itself (p. 71). As for Iran's ally Syria, Turkey should be encouraged to bring that country into its own "economic and political orbit," if possible, with the prize of ending its regional isolation if it moves away from Iran (p. 73).

As for the Arab-Israeli conflict, Turkey should be encouraged to play the role of a "neutral," "balanced" intermediary (p. 75) so as to increasingly help normalize Israel in the area, as well as of a "chief intermediary" in the region as a whole. To serve long-term American interests, the image of Turkey as an "independent" country has to be built up (p. 177), even at the expense of possibly challenging short-term American policies. Otherwise, later American policy concerns may end up diminishing that country's regional clout and respect (p. 178), thereby reducing its ability to serve long-term as well as over-all American interests.

Going through this important and easy-to-read book, one should not lose sight of Fuller's background as a former vice chairman of the CIA's National Intelligence Council. His advice, therefore, is likely to carry significant weight on the course and policy performance of high-level American officials. The book's strategic thrust, therefore, provides important signals that may help discern what is required of Turkey as it undergoes a process of policy reorientation, particularly under the JDP and, more generally, how American decision makers are liable to think, act, and respond. This renders Fuller's study particularly relevant for those interested in observing Middle Eastern regional and global strategic dynamics as they unfold.

Amr G. E. Sabet Department of Public Management Vaasa University, Vaasa, Finland 